\title{
PENGARUH PERMAINAN ULAR TANGGA TERHADAP KEMAMPUAN MENGGOSOK GIGI PADA ANAK SEKOLAH DASAR KELAS III DI SDN BARANANGSIANG KABUPATEN CIANJUR TAHUN 2017
}

\author{
${ }^{1}$ Chatarina Suryaningsih, ${ }^{2}$ Nunung Nurjanah, ${ }^{3}$ Siti Sartika \\ ${ }^{1,2,3}$ Stikes Jenderal Achmad Yani Cimahi \\ J1. Terusan Jenderal Sudirman-Cimahi 40533 \\ Telp. 022-6631622, Fax. 022-6631624 \\ Email : chatarina.surya@yahoo.com
}

\begin{abstract}
Abstrak
Anak usia sekolah merupakan masa dimana terjadinya pergantian gigi susu menjadi gigi permanen. Kurang pemahaman tentang perawatan gigi dan mulut akan beresiko terjadinya masalah kesehatan gigi dan mulut, sehingga perlu dilakukan pendidikan kesehatan sebagai upaya pencegahan dengan menanamkan perilaku yang baik sejak dini. Metode penelitian yang digunakan adalah penelitian quasi experiment dengan jenis pre and post testwithout control. Sampel dalam penelitian ini menggunakan total sampling dengan sampel sebanyak 20 responden dan data yang diperoleh dalam penelitian dianalisis melalui dua tahapan, yaitu univariat untuk mengetahui rata-rata dan bivariat untuk mengetahui pengaruh (t-dependent). Hasil penelitian didapatkan bahwa rerata nilai kemampuan sebelum 5,85 dan sesudah 10,05. Hasil penelitian didapatkan adanya pengaruh permainan ular tangga terhadap kemampuan menggosok gigi pada anak dengan nilai p value $=0,001$. Berdasarkan hasil penelitian ini penulis menyarankan agar metode pendidikan kesehatan dengan ular tangga dilakukan secara rutin untuk memperbaharui wawasan terhadap anak di SD, mendukung dan memotivasi anak dalam menggosok gigi yang baik dan benar.
\end{abstract}

Kata kunci: Anak usia sekolah, menggosok gigi, ular tangga

\begin{abstract}
School-aged children are the times when dental turnover becomes permanent teeth. Lack of understanding about dental and oral care will risk the occurrence of dental and oral health problems, so it is necessary to do health education as a preventive effort by inculcating good behavior early on. One of the health education methods that can be used is a health education method with a simulated snake ladder game. This study was designed to determine the effect of snake ladder game on brushing ability in elementary school. The research design of quasi experiment with pre and post test without control was done on 20 responden that is the third grade student of elementary school of SDN Baranangsiang with total sampling technique. Data collection using observation sheets.Analysis of data through 2 stages, namely univariate to see the average value of brushing and bivariate ability to see the difference or influence before and after using the t test dependent. The results showed the mean value of ability before 5.85 and after 10.05. Statistical test with $t$ dependent obtained $p$ Value $=0,001$, there is difference of mean value of brushing ability before and after health education by simulation method of snake ladder. So the method of health education with simulated snake ladder games can be recommended as an interesting new alternative method. It is recommended that health education method with snake ladder to improve oral hygiene is done regularly to renew the insight of children in elementary school, support and motivate children to brush their teeth properly andcorrectly by elementary school teachers.
\end{abstract}

Keywords: School-Age, Toothbrush, Snake Ladder 


\section{PENDAHULUAN}

Anak sekolah adalah anak pada usia 6-12 tahun, yang artinya sekolah menjadi pengalaman inti anak (Wong, 2008). Masa sekolah dapat dikatakan sebagai masa intelektual atau masa keserasian bersekolah. (Wijayanti, 2016).

Anak usia sekolah merupakan masa rentan terhadap masalah kesehatan gigi dan mulut. Pada masa ini gigi susu mulai tanggal satu persatu dan gigi permanen pertama mulai tumbuh pada usia 6-8 tahun. Dengan adanya variasi gigi susu dan gigi permanen bersamasama didalam mulut, menandai masa gigi campuran pada anak. Gigi yang baru tumbuh belum matang sehingga rentan terhadap kerusakan (Potter \& Perry, 2005).

Prevalensi penduduk Jawa Barat memiliki masalah pada gigi dan mulut mencapai $28,0 \%$ dan prevalensi anak-anak usia 10-14 tahun mengalami masalah pada gigi dan mulut mencapai 25,2\% (Riskesdas, 2013).

Anak-anak pada umumnya senang makan gula-gula, apabila anak terlalu banyak makan gula-gula dan jarang membersihkannya, maka gigi-giginya akan mengalami karies gigi. Keluhan dari sakit gigi dapat berakibat anak tidak mau pergi ke sekolah.

Kebiasaan menggosok gigi di Indonesia masih kurang baik. Survei Riset Kesehatan Dasar (RISKESDAS) tahun 2013 mengungkapkan bahwa prevalensi pada anak usia sekolah dalam kebiasaan menyikat gigi yang benar sebesar 1,7\%. Sebagian besar anak menyikat gigi setiap hari saat mandi pagi atau mandi sore.

Upaya pemeliharaan kesehatan gigi dan mulut sebaiknya dilakukan sejak usia dini. Usia sekolah dasar merupakan saat yang ideal untuk melatih kemampuan motorik seorang anak, termasuk diantaranya menggosok gigi
(Hidayat \& Tandiari, 2016). Salah satu upaya dalam peningkatan kesehatan gigi dan mulut adalah dengan metode pendidikan kesehatan (Riyanti \& Saptarini, 2012). Pendidikan kesehatan dapat dilakukan dengan berbagai macam metode, seperti ceramah, seminar, curah pendapat, dan bermain. Salah satu metode yang efektif adalah dengan metode bermain (Mardhiah, 2010).

Salah satu media yang umum dimainkan anak-anak adalah permainan ular tangga yang dimodifikasi kesehatan gigi dan mulut. Permainan ular tangga merupakan salah satu permainan kooperatif yang menarik, ringan, sederhana, mendidik, menghibur dan sangat berinteraksi jika dimainkan bersama-sama (Handayani, 2012). Permainan ular tangga ini sesuai dengan tumbuh kembang anak sekolah, khususnya pada anak usia 8-11 tahun. Anak yang berusia 8-11 tahun mulai dapat menerima suatu permainan yang banyak diwarnai dengan nalar dan logika yang bersifat objektif lainnya (Mahsun, 2011 dalam Supriyadi, Setyorini, Merry 2014). Permainan ini mengandung beberapa aspek yang mengajarkan kepada anak mengenai moral dan etika tentang kebaikan dan keburukan. Salah satu kebaikan yang diajarkan adalah mengenai pengetahuan, sikap, dan tindakan (Augustyn, 2004 dalam Yudianto, Mukarromah dan Yani 2012).

Hasil studi pendahuluan dengan melakukan observasi dan wawancara kepada 10 siswa kelas 3, diperoleh data ternyata setelah diobservasi masih ada 4 orang anak yang mengalami karies gigi, 2 orang anak yang ompong, dan 4 orang anak tidak mengalami karies, dan gigi ompong. Dari 10 orang siswa ada 1 orang anak yang mengatakan menggosok gigi setelah sarapan pagi, 9 orang anak mengatakan menggosok gigi saat mandi di pagi hari dan sebelum sarapan, sedangkan dari 10 orang siswa tersebut, 2 orang anak 
Pengaruh Permainan Ular Tangga terhadap Kemampuan Menggosok Gigi pada Anak Sekolah Dasar Kelas III (Chatarina Suryaningsih)

mengatakan menggosok gigi terlebih dahulu sebelum tidur, 4 orang anak mengatakan kadang-kadang menggosok gigi sebelum tidur, dan 4 orang anak yang tidak pernah menggosok gigi sebelum tidur. Lalu terkait kemampuan anak dalam menggosok gigi tidak sesuai dengan prosedur sebanyak 8 orang, dalam hal ini anak diminta untuk menggosok gigi oleh peneliti sesuai dengan kemampuannya lalu dibandingkan dengan lembar observasi yang peneliti miliki.

Tujuan penelitian ini adalah mengetahui pengaruh permainan ular tangga terhadap kemampuan menggosok gigi pada anak sekolah dasar kelas III di SDN Baranang siang Kabupaten Cianjur tahun 2017.

\section{METODE PENELITIAN}

Jenis penelitian menggunakan quasi experiment dengan rancangan pre and post testwithout control. Penelitian dilakukan di SDN Baranangsiang Kabupaten Cianjur. Populasi dalam penelitian ini adalah anak usia sekolah kelas III yang berusia 8-10 tahun yang ada di SDN Baranangsiang Kabupaten Cianjur tahun 2017 (pada bulan Maret sampai Mei) sebanyak 20 orang. Metode pengambilan sampel adalah total sampling, dengan besar sampel sebanyak 20 responden. Analisis yang digunakan adalah univariat untuk menentukan kemampuan menggosok gigi sebelum dan setelah dilakukan permainan ular tangga, dalam analisis ini menggunakan mean karena data berdistribusi normal, serta analisis bivariat untuk mengetahui pengaruh permainan ular tangga terhadap kemampuan menggosok gigi, dalam analisis ini diuji statistik menggunakan uji $\mathrm{T}$ dependen (uji parametrik).

Pengambilan data adalah sebagai berikut:

a) Pre Intervensi
1) Peneliti melakukan proses perizinan pada tanggal 10 Mei 2017.

2) Peneliti berkenalan dengan anak kelas III, menjelaskan tujuan, manfaat, prosedur penelitian, serta memberikan informed concent kepada orang tua dan meminta mengisi lembar persetujuan bagi orang tua yang bersedia anaknya dijadikan responden pada tanggal 10 Mei 2017.

3) Peneliti membagi responden ke dalam 4 kelompok, setiap kelompok beranggotakan 5 orang anak. Kelompok 1 dan 2 wanita, sedangkan kelompok 3 dan 4 laki-laki. Pembagian kelompok dilakukan pada tanggal 10 Mei 2017 dengan pembentukan kelompok disesuaikan dengan tempat duduk anak.

b) Pelaksanaan

1) Peneliti mempersiapkan alat yang digunakan untuk pelaksanaan menggosok gigi seperti gelas, air, sikat, pasta gigi dan tisu. Setelah peralatan sudah siap peneliti melakukan observasi kepada anak tentang menggosok gigi (pre test) untuk menilai kemampuan anak dalam menggosok gigi. Peneliti melakukan pre test selama 1 hari pada tanggal 13 Mei 2017, yang di bantu 2 observer yang sudah dipersamakan persepsi terlebih dahulu. Setiap observer menilai 1 orang anak dalam melakukan praktik tindakan menggosok gigi yang dilakukan di perkarangan sekolah.

2) Melakukan intervensi permainan ular tangga yang sudah dimodifikasi. Peneliti mempersiapkan peralatan yang digunakan dalam permainan ular tangga yaitu papan ular tangga, dadu, tempat kocokan dadu, dan bidak. Hari pertama anak diberikan permainan ular tangga disekolah SDN Baranangsiang, responden dibagi menjadi 4 kelompok, 1 kelompok terdiri dari 5 orang anak. 
Setiap kelompok diberikan permainan ular tangga sebanyak 4 kali karena berdasarkan penelitian yang dilakukan Sari, Ulfiana dan Dian (2012) bahwa setelah dilakukan 4 kali permainan ular tangga yang sudah dimodifikasi dapat meningkatkan pengetahuan, sikap, dan dapat mengaplikasikan tindakan menggosok gigi. Sedangkan hari kedua, ketiga dan keempat diberikan intervensi permainan ular tangga dirumah siswa (door to door). Mengingat tanggal 15-20 Mei 2017 siswa kelas 1 sampai 5 libur, sehingga peneliti memberikan intervensi secara door to door di empat tempat yaitu Kp. Dukuh, Kp. Jati, Kp. Sasak, dan Kp. Kedongdong dengan responden minimal 2 orang anak untuk memainkan permainan ular tangga, mengingat rumah siswa berdekatan sehingga anak dapat memainkan permainan ular tangga. Peneliti melakukan undian siapa yang berhak bermain terlebih dahulu. Dalam 1 kali permainan dilakukan dalam 20 menit dan setiap anak diwajibkan untuk membaca tulisan yang ada didalam kotak-kotak dalam permainan ular tangga, serta membaca langkah-langkah menggosok gigi yang tertera di balik permainan ular tangga. Anak yang tidak membaca tulisan yang ada dibalik papan permainan yaitu langkah-langkah menggosok gigi anak dihukum dengan tidak boleh melempar dadu pada putaran pertama sedangkan apabila anak tidak membaca tulisan yang ada dalam kotakkotak permainan ular tangga diberi hukuman dengan mundur 2 kotak dari kotak sebelumnya. Permainan dilakukan secara natural sehingga anak dapat bermain dan belajar dengan senang. Pemenang dalam permainan ular tangga diberikan hadiah. Pada saat melakukan intervensi peneliti meminta bantuan 2 orang asisten peneliti untuk mengawasi agar anak disiplin dalam mengikuti permainan (intervensi dilakukan selama 4 hari dengan selang 1 hari dari tanggal 1320 Mei 2017). Berikut penjelasan intervensi permainan ular tangga:

a) Permainan ular tangga pertama pada tanggal 13 Mei 2017

b) Permainan ular tangga kedua pada tanggal 16 Mei 2017

c) Permainan ular tangga ketiga pada tanggal 18 Mei 2017

d) Permainan ular tangga ke empat 20 Mei 2017

3) Membuat kontrak waktu dan tempat untuk evaluasi (post test) dengan anak.

c) Post Intervensi

Peneliti melakukan evaluasi (post test) yaitu mengobservasi kembali kemampuan menggosok gigi anak setelah dilakukan permainan ular tangga. Post test dilakukan selama 1 hari pada tanggal 20 Mei 2017.

\section{HASIL PENELITIAN}

Tabel 1.

Rata-rata Kemampuan Menggosok Gigi Sebelum Diberikan Permainan Ular Tangga

\begin{tabular}{lcccc}
\hline \multicolumn{1}{c}{ Variabel } & Mean & SD & $\begin{array}{c}\text { Min- } \\
\text { Max }\end{array}$ & $\mathbf{9 5 \%} \mathbf{C l}$ \\
\hline $\begin{array}{l}\text { Kemampuan } \\
\begin{array}{l}\text { Menggosok } \\
\text { gigi }\end{array}\end{array}$ & 10,05 & 1,317 & $8-13$ & $\begin{array}{l}9,43- \\
10,67\end{array}$ \\
\hline
\end{tabular}

Berdasarkan tabel 1. di atas menunjukkan bahwa kemampuan menggosok gigi pada anak di SDN Baranangsiang Kabupaten Cianjur sebelum diberikan permainan ular tangga adalah kurang dilihat dari nilai mean 5,85 tidak memenuhi standar pencapaian poin yang ditentukan yaitu dibawah skor maximal sebesar 13 poin. Pada pre test ini didapatkan hasil bahwa nilai kemampuan menggosok gigi pada 20 anak, terendah adalah 3 dan hasil nilai tertinggi adalah 8 . Berdasarkan estimasi 
Pengaruh Permainan Ular Tangga terhadap Kemampuan Menggosok Gigi pada Anak Sekolah Dasar Kelas III (Chatarina Suryaningsih)

interval disimpulkan bahwa 95\% diyakini bahwa rata-rata kemampuan menggosok gigi pada anak di SDN Baranangsiang Kabupaten Cianjur sebelum dilakukan intervensi adalah $5,13-6,57$.

Tabel 2.

Rata-rata Kemampuan Menggosok Gigi Setelah Diberikan Permainan Ular Tangga

\begin{tabular}{lcccc}
\hline Variabel & Mean & SD & $\begin{array}{c}\text { Min- } \\
\text { Max }\end{array}$ & $\mathbf{9 5 \%} \mathbf{C l}$ \\
\hline $\begin{array}{l}\text { Kemampuan } \\
\begin{array}{l}\text { Menggosok } \\
\text { gigi }\end{array}\end{array}$ & 5,85 & 1,531 & $3-8$ & $\begin{array}{c}5,13- \\
6,57\end{array}$ \\
\hline
\end{tabular}

Berdasarkan tabel 2. di atas menunjukkan bahwa kemampuan menggosok gigi pada anak di SDN Baranangsiang Kabupaten Cianjur setelah diberikan permainan ular tangga adalah baik dilihat dari nilai mean 10,05 dan sebagian besar anak memiliki tingkat kemampuan memenuhi standar pencapaian poin yang ditentukan yaitu 13 poin. Pada post test ini didapatkan hasil bahwa nilai kemampuan menggosok gigi pada 20 anak terendah adalah 8 dan hasil nilai tertinggi adalah 13. Berdasarkan estimasi interval disimpulkan bahwa 95\% diyakini bahwa rata-rata kemampuan menggosok gigi pada anak di SDN Baranangsiang Kabupaten Cianjur setelah dilakukan intervensi adalah 9,43-10,67.

Tabel 3.

Pengaruh Permainan Ular Tangga terhadap Kemampuan Menggosok Gigi

\begin{tabular}{lcccc}
\hline Variabel & Mean & SD & SE & $\begin{array}{c}p \\
\text { Value }\end{array}$ \\
\hline $\begin{array}{l}\text { Kemampuan } \\
\text { menggosok } \\
\text { gigi }\end{array}$ & & & & \\
$\begin{array}{l}\text { sebelum } \\
\text { dilakukan } \\
\text { permainan } \\
\text { ular tangga }\end{array}$ & 5,85 & 1,531 & 0,342 & \\
$\begin{array}{l}\text { Kemampuan } \\
\text { menggosok }\end{array}$ & & & & 0,001 \\
$\begin{array}{l}\text { gigi setelah } \\
\text { dilakukan } \\
\text { permainan } \\
\text { ular tangga }\end{array}$ & 10,05 & 1,317 & 0,294 & \\
\hline
\end{tabular}

Berdasarkan data yang terdapat pada tabel 3. didapatkan bahwa kemampuan menggosok gigi anak setelah dilakukan permainan ular tangga rata-rata nilainya adalah 10,05 dengan standar deviasi 1,317. Terlihat dari rata-rata perbedaan antara kemampuan menggosok gigi sebelum dan setelah dilakukan permainan ular tangga adalah 4,20 dengan standar deviasi 1,240 dimana rata-rata nilai kemampuan menggosok gigi mengalami peningkatan. Hasil uji statistik didapatkan nilai $p$ Value $=0,001$ maka dapat disimpulkan bahwa ada perbedaan yang signifikan antara kemampuan menggosok gigi anak sebelum dan setelah dilakukan permainan ular tangga.

\section{PEMBAHASAN}

\section{Kemampuan menggosok gigi pada anak sebelum diberikan permainan ular tangga}

Hasil penelitian menunjukkan bahwa rata-rata nilai kemampuan menggosok gigi pada anak sebelum diberikan permainan ular tangga adalah 5,85 (95\%CI: 5,13-6,57) yang berarti bahwa kemampuan menggosok gigi pada anak sebelum diberikan permainan ular tangga adalah kurang, dengan skor terkecil 3 dan terbesar 8. Hal ini karena kemampuan anak dalam menggosok gigi yang tidak memperhatikan gerakan-gerakan yang benar dalam tata cara menggosok gigi. Hal ini juga didukung dengan penelitian yang dilakukan oleh Wiradona, Widjanarko, dan Syamsulhuda (2016), dengan judul pengaruh perilaku menggosok gigi terhadap plak gigi pada siswa kelas IV dan V di SDN Wilayah Kecamatan Gajahmungkur Semarang, menunjukkan bahwa perilaku dalam menggosok gigi pada siswa kelas IV dan $\mathrm{V}$ masih kurang, karena siswa belum memahami cara menggosok gigi yang benar, lamanya menggosok gigi, dan kurang mengetahui ada beberapa gerakan menggosok gigi yang 
dianjurkan. Saat pre testsebagian anak tidak lulus pada lembar ceklis no 2,3,4,5,6, dan 9 .

Berdasarkan hasil penelitian, kurangnya kemampuan menggosok gigi pada anak sebelum diberikan permainan ular tangga yaitu disebabkan karena anak belum memahami atau tidak tahu cara menggosok gigi yang benar dan lamanya menggosok gigi. Anak hanya sebatas memahami menggosok gigi yang penting gigi sudah disikat. Anak kurang menyadari bahwa menggosok gigi harus memperhatikan gerakanmenggosok gigi pada setiap permukaan gigi. Disekolah juga belum berjalannya program usaha kesehatan gigi sekolah (UKGS) dengan baik.

Upaya pemeliharaan kesehatan gigi dan mulut yaitu tindakan menggosok gigi dan kumurkumur. Tindakan menggosok gigi merupakan hal yang utama dalam upaya pemeliharaan kesehatan gigi dan mulut. Menurut Riyanti dan Saptarini (2012), usia sekolah dasar merupakan masa yang ideal untuk melatih kemampuan motorik seorang anak, termasuk menggosok gigi. Peran orang tua dan guru dibutuhkan untuk menjelaskan, memberi contoh, membimbing serta mendorong anak untuk memiliki perilaku yang baik dan diharapkan.

\section{Kemampuan menggosok gigi pada anak setelah diberikan permainan ular tangga}

Hasil penelitian menunjukkan bahwa rata-rata nilai kemampuan menggosok gigi pada anak setelah diberikan permainan ular tangga adalah 10,05 (95\%CI: 9,43-10,67) yang berarti bahwa kemampuan menggosok gigi pada anak setelah dilakukan permainan ular tangga adalah baik, dengan skor terkecil 8 dan terbesar 13. Sehingga pada peneliti ini, kemampuan menggosok gigi pada anak mengalami peningkatan setelah diberikan permainan ular tangga yang sudah dimodifikasi. Hal ini karena pengetahuan anak mengalami perubahan dari yang awalnya tidak tahu menjadi tahu tentang cara menggosok gigi yang baik dan benar, yang dibuktikan pada saat pre test anak tidak tahu langkah menggosok gigi no 2,3,4,9, dan 11 setelah diberikan permainan ular tangga saat post testanak menjadi tahu langkah menggosok gigi tersebut. Hal ini tentu akan mengubah kemampuan anak dalam menggosok gigi dari yang kurang baik meningkat menjadi baik.

Sebagaimana yang dinyatakan Syafarudin (2012) bahwa kemampuan adalah suatu yang dipelajari yang memungkinkan seseorang melakukan sesuatu dengan baik, yang bersifat intelektual atau mental maupun fisik. Melakukan suatu tindakan ini melalui upaya yang sistematis dan rasional yang berakumulasi menjadi suatu keterampilan yang menghasilkan kecerdasan intelektual dan fisik melalui proses pengalaman, pendidikan dan latihan, sehingga dapat melakukan sesuatu itu lebih bermutu dan bermanfaat.

\section{Pengaruh Permainan Ular Tangga terhadap Kemampuan Menggosok Gigi pada Anak Sekolah Dasar}

Berdasarkan hasil penelitian yang tertulis pada tabel 3 diperoleh bahwa rata-rata nilai kemampuan menggosok gigi pada anak sebelum dilakukan permainan ular tangga adalah 5,85 yang menunjukkan kemampuan menggosok gigi pada anak adalah kurang, dan rata-rata nilai kemampuan menggosok gigi pada anak setelah dilakukan permainan ular tangga adalah 10,05. Hasil penelitian menunjukkan terdapat peningkatan dengan selisih 4,20. Hasil uji statistik dengan menggunakan $t$-dependen menunjukkanantara nilai awal dan nilai akhir kemampuan menggosok gigi anak didapatkan nilai $p$ Value $=0,001<\alpha=0,05$. Hal ini berarti bahwa hipotesis alternatif (Ha) terbukti yaitu terdapat 
Pengaruh Permainan Ular Tangga terhadap Kemampuan Menggosok Gigi pada Anak Sekolah Dasar Kelas III (Chatarina Suryaningsih)

pengaruh permainan ular tangga terhadap kemampuan menggosok gigi pada anak sekolah dasar. Berdasarkan hasil analisis diketahui bahwa terjadi peningkatan yang signifikan pada kemampuan menggosok gigi pada anak setelah dilakukan permainan ular tangga.

Hal tersebut disebabkan karena anak telah diberikan permainan ular tangga dengan sukarela dan tanpa paksaan. Media permainan ular tangga yang digunakan pada penelitian ini sebagai media edukasi yang dimodifikasi dengan langkah-langkah menggosok gigi yang benar, dan sebab akibat dari tidak menggosok gigi menunjukkan bahwa media ular tangga dapat berfungsi dalam peningkatan kemampuan menggosok gigi responden. Hal ini juga didukung dengan hasil penelitian oleh Sari, Ulfiana, \& Dian (2010), dengan judul pengaruh pendidikan kesehatan gosok gigi dengan metode permainan simulasi ular tangga terhadap perubahan pengetahuan, sikap, dan aplikasi tindakan gosok gigi anak usia sekolah di SD Wilayah Paron Ngawi, didapatkan hasil bahwa setelah diberikan permainan ular tangga itu efektif dalam meningkatkan pengetahuan, sikap, dan aplikasi tindakan menggosok gigi pada anak usia sekolah. Hal ini karena saat memainkan permainan ular tangga, mengikutsertakan panca indera, sehingga lebih menarik, lebih mudah dipahami, lebih menyenangkan karena anak bermain sambil belajar.

\section{KESIMPULAN}

1. Kemampuan menggosok gigi pada anak sekolah dasar sebelum diberikan permainan ular tangga adalah kurang mean $(5,85)$.

2. Kemampuan menggosok gigi pada anak sekolah dasar setelah diberikan permainan ular tangga adalah baik mean $(10,05)$.
3. Terdapat pengaruh permainan ular tangga terhadap kemampuan menggosok gigi pada anak sekolah dasar kelas III (nilai $p$ Value $=0,001<\alpha=0,05)$.

\section{DAFTAR PUSTAKA}

BPDANP Kesehatan. (2013). Riset kesehatan Dasar. Retrieved Maret 18, 2017, from www.depkes.go.id/resources/download/ general/Hasil\%20Riskesdas\%202013.p df.

Potter \& Perry. (2005). Fundamental Keperawatan. Jakarta: EGC.

Riyanti \& Saptarini 2012 dalam, Kurnia, S. E., Elida, U., \& Praba, D. (2017). Pengaruh Pendidikan Kesehatan Gosok Gigi dengan Metode Permainan Simulasi Ular Tangga terhadap Perubahan Pengetahuan, Sikap, dan Aplikasi Tindakan Gosok Gigi Anak Usia Sekolah di SD Wilayah Paron Ngawi. Retrieved April 18, 2017, from https://www.scribd.com/document/3386 77485/Ernita-K-docx.

Sari, Ulfiana, \& Dian. (2010). Pengaruh Pendidikan Kesehatan Gosok Gigi dengan Metode Permainan Simulasi Ular Tangga terhadap Perubahan Pengetahuan, Sikap, dan Aplikasi Tindakan Gosok Gigi Anak Usia Sekolah di SD Wilayah Paron Ngawi.

Syafarudin. (2012). Pendidikan dan Pemberdayaan Masyarakat. Medan: Perdana Publishing.

Wijayanti. (2016). Karakteristik Peserta Didik Usia Sekolah Dasar. Retrieved April 21, 2017, from https: //www.academia.edu/16809297/Karakte ristik_Peserta_Didik_Siswa_SD_dan_P enerapan_dalam_Pembelajaran_Di_Kel as. 
Widjanarko, B., Wiradona, I., \& Syamsulhuda. (2013). Pengaruh Perilaku Menggosok Gigi terhadap Plak Gigi Pada Siswa Kelas. Jurnal Promosi Kesehatan Indonesia Vol. 8 / No. 1 / Januari 2013.
Wong, D.L.,, Hockenberry, M.,, Wilson, D.,, Winkelstein, M.L.,, \& Schwartz, P. (2008). Buku Ajar Keperawatan Pediatric Volume 1. Jakarta: EGC. 